\title{
The Quest for God: Rethinking Desire
}

\section{Introduction}

This paper develops a theme I've been working on for a couple of years, and it concerns the question of how we are to view the nature of desire and its relation to value, humanity, and God. I've written about Schopenhauer, Nietzsche, and Levinas in this context, and I want today to add Sartre to the equation. It is agreed on all sides that desire is inextricably tied up with what it means to be human, but this has led to very different conclusions about the nature and value of our predicament given the differing conceptions of desire at work in the relevant discussions. My focus for today's discussion concerns the distinction between two seemingly mutually exclusive ways of conceiving of desire, namely, as lack or deficiency (option 1), or as plenitude or creativity (option 2). What it means to think of desire in either of these terms is obscure, and it'll be a task of my paper to offer some clarification. We can note at this preliminary stage, however, that the distinction is acknowledged by Plato in The Symposium (with an approving nod to the second, creative, conception), ${ }^{1}$ and this conception is likewise operative in the work of many religious thinkers, all of whom insist that this model fits the desire for God.

This latter point has been of the utmost significance to me, for it is a growing theme in contemporary Nietzschean scholarship - and more generally in the grand narrative of Western metaphysics as presented from this perspective - that anybody who has anything to do with God is committed to thinking of desire as a kind of lack, and that this conception goes hand in hand with a distrust and hatred of desire, and, by implication, a hatred of what it means to be human. The Nietzschean, by contrast, proposes an alternative conception of desire which corresponds to the second, creative, option, and which is intended to rescue us from the despair of passive nihilism - where we give up on the world and human life to succumb to nothingness. This is how the official story goes at least, and some of its elements are replayed in the following words of the atheist philosopher Gilles Deleuze (taken from an interview):

Desire: who except priests would want to call it 'lack'? ...Those who link desire to lack, the long column of crooners of castration, clearly indicate a long resentment, like an interminable bad conscience.

This quotation suits my purposes at several levels. First, one of my protagonists Sartre - treats desire as a kind of lack, but he is about as far removed from a priest as one could imagine. He does, however, possess a Nietzschean kind of religious sensibility, describing himself as an atheist who is obsessed with God's absence. Second, Levinas another protagonist - rejects this lack-model of desire to defend an alternative which sounds a lot like that the creative conception endorsed by Deleuze (and Nietzsche). Crucially, however, Levinas is a theist. Third, and differences notwithstanding, Sartre and Levinas both insist that desire is oriented towards God in some sense, that it is insatiable, and that it is fundamental to what it means to be human. The Nietzschean, by contrast, rejects all reference to God, but he agrees that desire is central to what it means to be human, and wants to be able to make sense of its insatiability.

What little I've said rules out the imposition of a straightforward disjunction between those (religious types) who treat desire as a kind of lack and those (the atheists) who do not. In what follows I want to clarify, link, and distinguish the relevant conceptions of desire, all the better to challenge the assumption that religion is the enemy of desire (and hence, life), and to get a clearer and less ideologically loaded picture of what it means to comprehend desire in either or both of these ways. I shall question Sartre's insistence that man is a 
'useless passion', trace it back to his commitment to his lack model of desire, and argue that this model stands in the way of the more creative conception which is lurking in the background of his account. There will be a question of whether the atheist is entitled to this creative conception, and I shall challenge his assumption that it becomes available only when theism is overthrown. I shall suggest also that there is something important to be salvaged from the lack model.

\section{Sartre on desire as lack and the desire to be God}

In Being and Nothingness Sartre tells us that '[t]o be man means to reach toward Being God. Or if you prefer, man fundamentally is the desire to be God'. ${ }^{2}$ In offering this conception of man Sartre is in agreement with all those who posit a fundamental desire to underlie and structure all other desires - think of the concept of eros in Plato's Symposium, ${ }^{3}$ Freud's libido, ${ }^{4}$ Schopenhauer's will, and the desire for God as proposed by theologians such as Augustine and Aquinas. The typical theologian's conception of the desire for God is not a desire to be God, although he is happy to talk of wanting union in this context, and we shall see from Levinas that it makes sense to say of one who gives expression to such desire in the context of a human life that she does God's work, taking over from Him in this respect. However, it is no part of such a picture that God has been jettisoned in favour of man, although it is a common theological thought that there is a (diabolical) temptation in this direction. As Heidegger put it, man 'contends for the position in which he can be that particular being who gives the measure...for everything that is'. 5

Sartre is an atheist, albeit one who finds God's absence both distressing ('all possibility of finding values in a heaven of ideas disappears along with him, ${ }^{6}$ and liberating (we are alone, with nothing to cling to, and with no excuses). The God he rejects is defined in opposition to man, and with reference to the metaphysical framework it is his purpose to defend. Thus understood, God represents an ideal synthesis of being and consciousness - initself-for-itself as Sartre puts it in deference to the Hegelian language he inherits, although the basic idea is familiar from much traditional theology. ${ }^{7}$ God is being-in-itself by virtue of involving no lack, no longing, no imperfection; He is being-for-itself by virtue of being selfconscious and self-grounding. Sartre associates this ideal with beauty, love, and supreme value, but claims that it is an impossible synthesis because the relevant dimensions of being resist valid coordination (inevitably so if selfhood is inextricably tied to lack). He concludes that God (and the associated values) cannot exist.

Sartre's reasoning can be disputed, and there is a question of how seriously he takes these rational considerations in any case. Either way, he remains steadfast in his atheism, and denies on this basis that the desire to be God can be satisfied. So man cannot become God, and this, for Sartre, means that the desiring subject is a 'useless passion': man desires to be God, but this aim can never be completed. It is in this sense that we are incomplete or lacking beings - defined by an impossible desire, desire itself being understood as a lack within the subject. As Sartre puts it, 'desire shows that human reality is a lack', 'desire is the being of human reality', it is an 'incomplete circle that calls for completion'(BN 111); it is 'a lack of being. It is haunted in its inmost being by the being of which it is desire...it bears witness to the existence of lack in the being of human reality' (BN112). We are said to experience ourselves as failures in this respect - 'the for-itself in its being is failure...in the presence of the being which it has failed to be', we are 'haunted by' and 'thirst for' being (BN 114).

We can agree that we lack the perfections of God, and it makes sense to say that we are incomplete in this respect, but only on the assumption that we are to be defined in contrast to such a being. Sartre claims not merely that we are lacking in this respect, but that this lack manifests itself as desire, that this desire is fundamental to our motivational make-up, and 
that it is a desire to be God. He claims also that we 'thirst' for God, and that this thirst is experienced as a deficiency or failure.

The idea that we 'thirst' for God is familiar from biblical and theological literature, and although the imagery brings connotations of wanting to assimilate or possess, it is more properly understood - in these contexts at least - as capturing the mesmeric attraction at issue when we are drawn towards God in this manner. Sartre seems at times to be conceding to such a picture, when, for example, he talks of desire being haunted by the being of which it is desire. However, such a picture is at odds with his atheism, and it is at odds also with his more prevalent message that the desire in question wants to be the being it desires.

Thus far, the message seems predominantly bleak: the desiring subject can never find the fulfilment she craves, she is irreducibly unhappy in this respect, and filled with a sense of failure. So our experience as desiring beings is tied up with this sense of failure, and Sartre takes this to be borne out in the frustrations we experience at the level of everyday desires and satisfactions, and in our attempts to find happiness in the realm of interpersonal relationship. Erotic love is just one more context in which the desire to be God is enacted and frustrated - this time in one's desire to be God in the eyes of the 'beloved', and the problem extends more generally to undermine the possibility of love across the board. As Kate Kirkpatrick puts it in her recent book on Sartre on sin, his critique of love - 'which seeks and fails to fulfil the lover's lack....extends to all human loves: every profession of love, on his view, is a masquerade...amour-propre masquerades not only as eros, but as agape and philia'; other people are simply 'cast offs we leave behind in the wake of our selfaggrandisement'. (p.209).

There is no love in Sartre's worldview - which helps to explain why God - whom Sartre associates with love - appears only in the guise of an egoistic desire to take His place. All is not entirely bleak, however, for in the midst of this 'abyss' there emerges a more optimistic picture - one which follows on from the picture of human reality as lack, and which suggests that it has the potential to bring forth a kind of creativity or productivity. It does so in two senses. First, we are told that 'desire by itself tends to perpetuate itself; man clings ferociously to his desires', ${ }^{8}$ and Stephen Wang talks in this context of 'the refusal to rest satisfied, the constant push forward', the necessity [] of going beyond and building something new'. 'Second, our nature as lacking beings is bound up with our freedom, for freedom:

coincides at its roots with the non-being which is at the heart of man', and '[f]or a human being, to $b e$ is to choose himself; nothing comes to him either from without or from within himself that he can receive or accept. He is wholly and helplessly at the mercy of the unendurable necessity to make himself be.

Sartre's idea that we cling ferociously to our desires, when wedded to the suggestion that they are experienced as a source of pain, brings to mind a rather desperate insistence of the ego or will. It might be thought to suggest also, however, that they are a force for the good, motivating us to pursue our ends and make something of ourselves in the process. We are to suppose that this is a uniquely human way of existing, and it is clear from what he goes on to say that desire's productivity in this context is inextricably tied up with the possibility of value. Having seemingly ruled out - in the above quotation - that value could have its source in something beyond the subject, Sartre speculates that our freedom will reveal itself as 'the unique source of value and the nothingness by which the world exists'. The moral agent, he continues, will see that he is 'the being by whom values exist' ${ }^{10}$ This possibility and its consequences is left open, and it is left equally open that freedom will remain ever defined 'in relation to a transcendent value which haunts it'. 
Sartre seeks to defend the possibility of reinventing meaning and value in a world without God. Desire is a fundamental ingredient in this context because there is value to be found in desire - we cling ferociously to them, and they move us to pursue our ends - and it involves a kind of creativity in these respects. The creativity at issue here concerns desire's motivating force and Sartre wants to reject any explanation which involves reference to an independently existing realm of value. So there are no prospects for saying that value motivates our desires, and the alternative seems to involve tracing the source of value to the desiring subject whatever this really means. One thing it could mean is that value is determined by the desiring subject in the sense that $\mathrm{x}$ is valued if $\mathrm{x}$ is desired. However, this seems to involve just one more attempt to play at being God - a hopeless attempt if, in line with the official metaphysics, desire and value are to be dualistically opposed. By contrast, if this framework is rejected, then the question is whether there is an alternative conception of desire which is better equipped to accommodate its creative and value-producing potential. It is a task of the following section to explore this possibility, initially in the context of an atheistic framework which purports to free us once and for all from the transcendent value that haunts us.

\section{From lack to creativity}

The lack model of desire is a familiar object of attack for the typical Nietzschean. Such a figure shares Sartre's atheistic stance, but insists that such a model is symptomatic of the theistic framework to which we remain beholden. No wonder it is so difficult to make sense of meaning and value if our framework dictates that they are unattainable! So it is agreed that we are desiring beings, and that desire is a distinctively human capacity which is tied up with life and value. What is denied, however, is that these connections can be made good from within a lack-involving conception of desire. Robert Pippin sums up the agenda as follows:

We want a picture of striving without the illusion of a determinate, natural lack that we can fill. To anyone with an intellectual conscience, it will have to feel as though there just can be no human whole, not as proposed by Plato or Aristotle or Christianity or Schiller or Hegel, and so forth, and yet it can't just "not matter" that there can be no such harmony or completion, because all of the ways we have come to think about such desire start out from these assumptions about caused needs or an incompleteness that we strive to complete. ${ }^{11}$

The first thing to note is that it is not invariably an illusion to suppose that striving involves a determinate, natural lack that we can fill, for the picture appropriately fits at least some of our desires - for example, the appetitive desires at issue when we feel hunger and thirst. Levinas will describe such desires in precisely these terms, classifying them as 'needs', and claiming that they stem from a lack in the subject which is filled by consuming or 'assimilating' an object that satisfies the desire. ${ }^{12}$ As he puts it, "I can "feed" on these realities and to a very great extent satisfy myself, as thought I had simply been lacking them'. ${ }^{13}$ These desires have their origin in us, they stem from our biological nature, and Levinas is anxious to distinguish them from the kind of desire which is at issue in the present discussion, namely, that which is fundamental to what it means to be human, and inextricably tied up with the question of value.

Let us grant that there could be a picture of striving without the illusion of a determinate, natural lack that we can fill, but how are its details to be understood? Pippin introduces the proposed alternative in the context of a discussion of the Death of God and Nietzsche's remark that Brahms 'does not create out of an abundance; he languishes for abundance'. ${ }^{14}$ This is what Pippin says: 
This distinction between desire as a lack and the death of God as a new lack and desire as abundance, excess and so the death of God as freeing such generosity will emerge frequently in what follows. ${ }^{15}$

We are familiar with the idea of desire as lack - it is associated with the theistic picture to be rejected, and involves seeing the desiring subject as striving towards a completion or perfection that she lacks (either contingently or in principle). The suggestion now is that one who is wedded to this conception of the desiring subject will take God's absence to be a further expression of the relevant lack, or a new occasion for languishing in it. This provides an accurate description of Sartre's position. By contrast, there is an alternative conception of desire which liberates us from this tragic conception of humanity, and which becomes available only when God is out of the picture (even as an unattainable ideal). According to this alternative conception, desire is to be understood as abundance or generosity. Pippin refers in this context to Nietzsche's talk of an 'overflow' of 'outpouring forces', and his use of the image of the beehive overloaded with honey. ${ }^{16}$ The implication here is that we have desire in abundance. But to repeat the questions we raised in our discussion of Sartre: where does it come from? What keeps it going? And what is its nature?

\section{Unrequited love}

Pippin is concerned with the question of how such desire is to be sustained, for he associates nihilism with its failure - the "flickering out of some erotic flame' ${ }^{17}$, as he puts it - and takes Nietzsche to be concerned with the problem of how it is to be reignited. There is a concession here to Plato and Augustine in the sense that the desire at issue is erotic, but the Nietzschean supposedly parts company with this framework by conceiving of desire as an overflow of outpouring forces rather than as a lack to be filled. I have already challenged the assumption that this conceptual shift is the prerogative of the atheist by noting that Levinas is similarly dismissive of the 'lack' model as it applies to our properly human desires. I have noted also that an analogous conceptual shift is enacted by Plato in The Symposium, and the notion of an effusive or outpouring force is often used to describe the loving desire which comes from God - this 'infinite overflow of love' in which we participate when we reach out to others. This description comes from Max Scheler who talks also of an 'abundance of vital power', ${ }^{18}$ quoting Matthew's claim that '[a] good man out of the good treasure of his heart, bringeth forth good things'. ${ }^{19}$ A paradigm of what it could mean for desire to be productive of value, albeit with no implication that it is the heart's desire that determines what counts as good.

Nietzsche likewise uses Matthew's image of the heart's treasure, citing with approval his ' $[\mathrm{w}]$ here your treasure is, there will your heart be also' ${ }^{20}$ Assuming, however, that theism has been rejected, then the heart's treasure in this context cannot have its source in the infinite overflow of God's love, and cannot be understood to be oriented in this direction. It is in the context of tackling the question of how its source and trajectory is to be understood that Pippin appeals to the image - taken from Nietzsche - of the unrequited lover. Not one who hankers after an inaccessible object (the lack model), but one who loves her unrequited love, and which she would 'at no price relinquish for a state of indifference'. ${ }^{21}$ Hence:

[T]he possibility of such an unrequited love, especially the possibility of sustaining it, turns out to be one of the best images for the question Nietzsche wants to ask about nihilism and our response'. ${ }^{2}$

The aim here is to accommodate desire's effusive power without reference to an external source and object (God's infinite desire/love). The image of the unrequited lover 
offers a model for what it could be for such desire to be sustained, but only if the object of desire is the unrequited love itself rather than some inaccessible object. The idea here seems to be that if we could explain the possibility of desiring a desire for its own sake rather than for the sake of its inaccessible object, then we should have an explanation of how there could be a self-generating desire which was not to be comprehended in lack-involving terms.

Levinas seems to have some such picture in mind when, in the context of defending his own anti-lack conception of desire he says that 'it nourishes itself...with its hunger', ${ }^{23}$ and has nothing to do with wanting food. ${ }^{24}$ It is fundamental to his position, however, that something comes to the desiring subject from without which she can receive and accept (to revert to Sartre's description of the position to be avoided), and he concludes on this basis that desire has its source in something beyond the desirer which 'animates' the desire. ${ }^{25}$ This something - its 'object' - is referred to as 'the Desirable', ${ }^{26}$ 'the Other', ${ }^{27}$ 'the Most High', ${ }^{28}$ 'the Invisible' 29 , 'the Transcendent', ${ }^{30}$ 'Infinity', ${ }^{31}$ and desire thus understood is described as 'Revelation'. ${ }^{32}$ We are left in no doubt about its theistic significance.

So Levinas commits the cardinal sin as far as our atheist protagonists are concerned. Crucially, however, he agrees that we must reject the lack conception of desire - as he puts it, desire is 'not an appeal to food', ${ }^{33}$ - and has nothing to do with wanting completion: it 'desires beyond everything that can simply complete it' ${ }^{34} \mathrm{He}$ agrees also that the desire at issue here is fundamental to our humanity. The idea that it is beyond any appeal for food allows Levinas to reject the idea that God is there simply to satisfy us. Indeed, he wants to deny that God is there to satisfy in any sense at all, this going hand in hand with the further claim that its object serves to 'hollow out' the desire rather than to fill it: 'the true Desire is that which the Desired does not satisfy, but hollows out'. ${ }^{35}$

Levinas is trying to capture what it means for desire for God to be insatiable, albeit in a framework which involves a rejection of the lack model. Desire is insatiable on the lack model in the sense that it fails to reach the desired object and is ever present for that reason. We are to suppose that satisfaction would bring it to an end. On the alternative Levinasian model, by contrast, desire is insatiable in the sense that it is animated by something beyond the subject - something which fills us with 'higher thoughts' rather than food, and which cannot in any case be grasped as an object. The idea here is that we move towards God only in so far as we are motivated to be moral, and Levinas would reject any attempt to reduce the relevant desire to a desire for fulfilment. We have also moved away from the (Sartrean) idea that desire is to be defined in opposition to God. Levinasian desire is essentially Godinvolving (he is an externalist about desire in this respect), although to repeat, God is experienced in and through the desire, and in the loving movement which leads us away from our selfish concerns to the needs of others.

It follows from all of this that there are two senses in which Levinasian desire counts as creative: first, it is constantly renewed/'hollowed out' by its (independently desirable) object, where this involves the subject being attracted in this direction; second, and in line with the requirement that God cannot be represented as an object, this attraction is expressed in the subject's motivation to be moral (God is known at the level of action rather than contemplation: 'to know God is to know what is to be done'.) Levinas can therefore grant with Sartre that creative desire is tied up with the question of value. He can say also that value has its source in the subject, meaning by this that the desiring subject is motivated to bring value to the world, and that the weight of responsibility is on her shoulders in this context - Levinas talks of God hiding His face to demand the superhuman of man. ${ }^{36}$ What he denies, however, is that the subject's desire determines what counts as valuable. On the contrary, she is conscious of 'Good, and the Law' in this context, ${ }^{37}$ and filled with the 'higher thoughts' which come from an acknowledgment of God's greatness. ${ }^{38} \mathrm{We}$ are told here that 
'[s]pirituality is offered up as absence', although this is not intended to compromise the idea that God is 'real and concrete'. ${ }^{39}$

Talk of God's absence returns us to Sartre, and there is a sense in which he, too, seeks to exploit this absence as an opportunity for erecting an ethics. The difference, however, is that he takes God's absence to be equivalent to non-existence, and concludes on this basis that there is no genuine love in the world, and no hope for fulfilment either. Levinas is happy to grant that fulfilment must elude us, but this is because he rejects the lack model of desire, seeing the desire for fulfilment as just one more expression of egoism. Furthermore, and in contrast to Sartre, he wants to say that there is genuine love and goodness in the world, but only because it contains desiring beings like ourselves who are motivated to be moral. In such a context we do God's work, the most significant example for Levinas being when we stand in moral relations to others. It is at this level of interaction that we are said to 'express' the infinite. ${ }^{40}$

\section{Atheism, again}

Levinas offers a picture of striving without the illusion of a lack to be filled, but his position confronts a seemingly obvious difficulty, namely, that it presupposes the truth of theism. Yet it is a non-negotiable premise of our atheist protagonists that theism is unsustainable, and that our only hope in the face of the abyss is to able to make sense of a conception of desire (and hence meaningful life and value) which is shorn of any reference to God. Hence the requirement for a conception of desire which is self-sustaining in an atheistic sense.

The truth of atheism is taken for granted in such discussions, but it is worth emphasising that this has not been established, and it is certainly not established by anything said by Nietzsche, Sartre, or their latter day disciples. After all, Levinas himself goes on about God's absence, but he would insist, as Paul Moser has recently put it, that the true God is hardly in 'the trivial entertainment business regarding our coming to know His existence', and that $\mathrm{He}$ is made present, if at all, at the level of morality.

This much narrows the gap between atheism and theism. Yet it is surely incumbent upon us to consider whether a properly atheistic position could be made good in this context, and what the implications are for an understanding of desire, value, and humanity. In this context too we want to be able to say that desire is self-nourishing, and in such a way that there is a creation of value in some sense. The most radical option is to say that nothing is objectively valuable, and that the agent's desire creates any value in its object. There is a question of how such desire could be sustained, but even if this were possible, it is unclear that it could support a properly human existence. To be sure, there is a danger here of begging the essential question, and the Nietzschean could respond that it should not be assumed that a properly human existence involves embodying value in the moral sense with which Levinas is concerned (creating value in this sense). Such a response suggests a move away from radical subjectivism - some values are better than others - and the Nietzschean could add that Levinasian value - and more generally, the values of Judaeo-Christianity warrant rejection because they are anti-life. This makes sense of Nietzsche's obsession with the future of humanity, although it raises the question of the limits of the morality under attack. After all, Scheler's conception of authentic Christian love sounds a lot like Nietzsche's will to power, and will to power has been interpreted so as to suggest that Nietzsche, no less than Levinas, is offering up spirituality as absence. ${ }^{41}$ Understood from this perspective, it is unhelpful to insist that the real difference comes with the rejection of God.

\section{Picking up the pieces}

In a paper on the abyss Grace Jantzen is concerned with the question of how the nihilist's loss of value might be transformed into possibilities for new growth. This is the question with 
which we have been wrestling, the central issue being whether this new growth could be sustained at the level of desire and in the absence of God. Towards the end of her paper Jantzen suggests that perhaps Heidegger is right when he says that only a god can save us now. She quickly adds, however, that 'God will come only as love is born within us, only as we ourselves become divine'. Her paper as a whole is concerned to defend this possibility, and to do so with reference to the conception of abyss assumed by some medieval mystics (her focus is Hadewijch). According to this conception the abyss refers to the unfathomable abyss of the divine nature and the human heart rather than the hellish groundlessness exploited by the likes of Sartre and Nietzsche, and Jantzen seeks to exploit this conception order to effect a reconfiguration of nihilism: yes, we face the abyss, and thank the lord for that!

It should be clear from my discussion that the real problem is determining whether this reconfiguration is permitted in the first place. I have argued that we are entitled to move beyond Sartre's framework - at least in the sense that we do not have to accept his conception of desire as lack, or the related assumption that we are fated to pursue an impossible ideal. So hell can be avoided to this degree at least, and we can surely question his insistence that the world which stands before us 'hath really neither joy, nor love, nor light'. This is not to suggest that atheism has been refuted. The point is simply that we are not obviously in hell. My Nietzschean agrees that we must move beyond Sartre in these respects, his aim being to effect the transition from abyss 1 (hell) to abyss 2 (heaven) from the resources of the human heart alone, as if we ourselves are infinite. This is the interesting move, and I have sought to determine the different things it could mean, whilst narrowing the gap between this option and its theistic rival. I have questioned the most radical interpretation of the Nietzschean position (value as reducible to desire), for it is surely just one more expression of the Sartrean desire to be God. Jantzen, of course, is happy to talk of our becoming divine when love is born within us, but she is not suggesting that God has been cast aside in favour of man, and is more properly understood to be articulating - a la Levinas - the sense in which we are caught up in the love of God.

It has been fundamental to what I've said that our creative activity - our value making - has its source in something beyond us, and must operate from within this constraint. So we do not create the values which attract us at the level of desire, and not all of our desires are oriented towards the good in any case. It surely makes sense to say that we are shown to be lacking in these respects, and this brings me to my final point which is that, Deleuze and others notwithstanding, there is an insight in the lack model of desire which we can ignore only at the cost of reverting to Sartre's impossible ideal. Crucially, however, this model is now articulated from within a framework which involves a denial of the Sartrean assumption that we are hitting a brick wall in this context - ever fated to remain out of touch with what we really want. The other important implication - which follows on from the idea that desire for God is 'hollowed out' by its object rather than eliminated - is that although it makes sense to say that the relevant lacks (or some of them) are capable of elimination, this occurs, if at all, only as the desire for God expands. This, I contend, is what it really means for the desiring subject to be creative: desire, who except priests are entitled to call it creative!

\footnotetext{
${ }^{1}$ See Symposium 206c where Plato takes us from a conception of desire as lack to desire as 'creating out of abundance' or 'giving birth in beauty'. As R.L. Markus puts it: "this "desire” is now of a being already complete or "perfect"...indeed, complete to overflowing, no longer is it thought of as a lack. This desire is not for something to be obtained - the beloved - but for giving something of itself', 'The Dialectic of Eros in Plato's Symposium', Downside Review, no. 233, 1955.

${ }^{2}$ Being and Nothingness (Henceforth BN), trans. Hazel E. Barnes (New York, 1956), p.566.

${ }^{3}$ Hazel Barnes draws the parallel with Plato's eros in her Introduction to BN, p.xxvii.

${ }^{4}$ Freud implies that the parallel between his own position and Plato's exists at the level of content as well as structure. Hence: 'In its origin, function, and relation to sexual love, the 'Eros' of the philosopher Plato
} 
coincides exactly with the love-force, the libido of psychoanalysis', Group Psychology and the Analysis of the Ego, http://freudians.org/wp-content/uploads/2014/09/Freud_Group_Psychology.pdf, p.90.

5 'The Age of the World Picture', in The Question Concerning Technology and Other Essays, trans. William Lovitt (New York: Harper and Row, 1977), p.134.

${ }^{6}$ Hence: 'Existentialism isn't so atheistic that it wears itself out showing that God doesn't exist. Rather, it declares that even if God did exist, that would change nothing', Existentialism and Humanism

${ }^{7}$ BN, p. 194 .

${ }^{8}$ BN, p.101.

9 'Human Incompletion, Happiness, and the Desire for God in Sartre's Being and Nothingness', Sartre Studies International, Volume 12, Issue 1, 2006, pp.8-9.

${ }^{10} \mathrm{BN} 627$.

11 'The Erotic Nietzsche', p.187.

${ }^{12}$ Totality and Infinity, trans. Alphonso Lingis (Pittsburgh: Duquesne University Press, 1969), p. 117.

${ }^{13}$ Totality and Infinity, p.34.

${ }^{14}$ Nietzsche, The Case of Wagner, in Basic Writings of Nietzsche, trans. Walter Kaufmann (New York: The Modern Library, 1968), p.643.

15 'Love and Death in Nietzsche', in Religion after Metaphysics, ed. Mark Wrathall (Cambridge: Cambridge University Press, 2003), p.9.

${ }^{16}$ See footnote 19. See also Thus Spoke Zarathustra, p.5: 'Insatiably your soul strives for treasures and gems, because your virtue is insatiable in wanting to bestow/You compel all things to and into yourselves, so that they may gush back from your well as the gifts of your love'.

17 'The Erotic Nietzsche', p.177.

${ }^{18}$ See Ressentiment, trans. Lewis B. Coser and William W. Holdheim (Milwaukee, Wisconsin: Marquette University Press, 2003), ch 3, p.64.

${ }^{19}$ Matthew 12.34. Scheler, p. 67.

${ }^{20}$ See footnote 19.

${ }^{21}$ This is the passage in full: 'Restless discovering and divining has such an attraction for us, and has grown as indispensable to us as is to the lover his unrequited love, which he would at no price relinquish for a state of indifference perhaps, indeed, we too are unrequited lovers!', Daybreak: Thoughts on the prejudices of morality, 429, eds. Maudemarie Clark and Brian Leiter; trans. R.J. Hollingdale (Cambridge: Cambridge University Press, 1997).

22 'The Erotic Nietzsche', p.187.

${ }^{23}$ Totality and Infinity, p.34.

${ }^{24}$ Totality and Infinity: An Essay on Exteriority, trans. Alphonso Lingis (Pittsburgh: Duquesne University Press, 1969), p.63.

${ }^{25}$ Totality and Infinity, p.62.

${ }^{26}$ Totality and Infinity, p.35.

${ }^{27}$ Totality and Infinity, p.35.

${ }^{28}$ Totality and Infinity, p.35.

${ }^{29}$ Totality and Infinity, p.35.

${ }^{30}$ Totality and Infinity, p.78.

${ }^{31}$ Totality and Infinity, p.78.

${ }^{32}$ Totality and Infinity, p.62.

${ }^{33}$ Totality and Infinity, p.63.

${ }^{34}$ Totality and Infinity, p.33.

35 'Philosophy and the Idea of the Infinite', p.114.

36 'Loving the Torah More Than God', p.145.

37 'A Religion for Adults', pp.20-22.

38 'Loving the Torah More Than God', p. 145.

39 'Loving the Torah More Than God', p. 145.

${ }^{40}$ Hence: "The infinite is not "in front of me"; it is I who express it, but I do so precisely in giving a sign of the giving of signs, of the " for the other" in which I am disinterested: here I am [me voici]', 'God and Philosophy, in Of God Who Comes to Mind, trans. Bettina Bergo (Stanford: Stanford University Press, 1998), p. 75.

Compare Simone Weil: "God must be on the side of the subject and not on that of the object during all those intervals of time when, forsaking the contemplation of the light, we imitate the descending movement of God so as to turn ourselves towards the world', The Notebooks of Simone Weil, vol. 2, trans. Arthur Wills (London: Routledge, 1976), p.358. 
${ }^{41}$ See Jacob Golomb's 'Will to Power: Does it Lead to the "Coldest of all Cold Monsters"?', The Oxford Handbook of Nietzsche, eds. John Richardson and Ken Gemes (Oxford: Oxford University Press, 2013), p.526. 